\title{
EXCHANGE RATE DYNAMICS IN SOUTH AFRICA
}

\begin{abstract}
The structure of the nominal exchange rates in South Africa is examined by using fractional integration. We investigate the levels and the volatilities against the US dollar, the British pound, the Euro, the Japanese yen, the Chinese yuan, the Australian dollar, and the Botswanan Pula. The results indicate that most series are $\mathrm{I}(1)$ and though there is some evidence of mean reversion, the orders of integration are close to 1, implying high levels of persistence. Only for the Bostwana Pula is there evidence of mean reversion in various subsamples. For the volatilities, stationary long memory is observed in all cases.
\end{abstract}

Keywords: Exchange rate dynamics; long memory; persistence; fractional integration; South Africa

JEL Classification': C1, C15, C22, C53, C75

${ }^{1}$ Comments from the Editor and an anonymous reviewer are gratefully acknowledged. 


\section{Introduction}

Instabilities in exchange rates especially with the major trading currencies such as the United States Dollar (USD), the British Pound (GBR) and the Euro (EUR) have become a major source of concern to all developing countries in relation to their currencies, including South Africa in relation to the Rand (ZAR). This is because a significant amount of business and trade is transacted in these currencies, hence an ability to control volatilities, induced mostly by the persistency of economic shocks and other unobserved factors, is essential, especially for policy formulation.

A number of research works, including but not limited to Gil-Alana (2000, 2004), Sauer and Bohara (2001), Benigno (2004), Tenrehyro (2007), Anderson et al. (2011), Caporale and Gil-Alana (2004, 2013), Lo and Morley (2015) among others, have been conducted in this area, all in the 'name' of ascertaining the effects of exchange rate volatilities among currencies across the globe. For instance, Gil-Alana (2000) examined the real exchange rate data between the USA and five industrialized countries. His results indicate mean reversion if the disturbances are autocorrelated. Sauer and Bohara (2001) used a large panel of industrialized and developing countries to investigate the link between exchange rate volatility and exports and found different volatility measures, which indicated that negative effects exist for the exports of less developed countries (LDC), especially from Latin America and Africa, but not for exports from Asian LDCs or industrialized countries.

Benigno (2004) also conducted a study on the effects of alternative monetary rules on real exchange rate persistence. By means of a two-country stochastic dynamic general equilibrium with nominal price stickiness and local currency pricing, they found no proportional relationship between the time during which prices remain sticky and the persistence of the response of the real exchange rate. Their research emphasized, to a 
certain extent, the role of interest rates smoothing policies and relative price stickiness within countries in understanding the relationship between the real exchange rate and monetary shocks. Caporale and Gil-Alana (2004) employed the concept of fractional integration and cointegration to model the deutschemark, DM - US dollar and the yen US dollar real exchange rates in terms of both monetary and real factors, more specifically real interest rate and labour productivity differentials. Their results revealed that whereas the individual series were integrated of order 1 , their long run relationships were suspected to have a fractionally cointegrated structure. Tenrehyro (2007) investigated the effect of nominal exchange rate variability on trade, using a novel approach and presenting new estimates from a broad sample of countries from 1970 to 1997. The estimates indicated that nominal exchange rate variability has no significant impact on trade flows.

Anderson et al (2011) employed high-frequency data on deutschemark and yen returns against the US dollar and constructed model-free estimates of daily exchange rate volatility and correlation that covered an entire decade. They found noteworthy results, which included a normality-inducing volatility transformation, high contemporaneous correlation across volatilities, evidence of long-memory dynamics in volatilities and precise scaling laws under temporal aggregation. Caporale and Gil-Alana (2013) analysed long-memory properties of a high-frequency financial time series dataset. The paper focused on temporal aggregation and other features of the data, and how they might affect the degree of persistence. A fractionally integrated model was estimated with a variety of specifications for the error term. A lower degree of integration was found to be associated with lower data frequencies. In particular, for lower frequencies, values of $d$ strictly smaller than 1 were found, implying mean-reverting behaviour; however, for higher data frequencies the unit root null cannot be rejected, with data collected every 10 minutes. 
This was true for all four series examined, namely open, high, low and last observations for the US dollar/British pound spot exchange rate and for different sample periods.

Lo and Morley (2015) also investigated the persistence of real exchange rates using Bayesian methods. In comparison with standard grid-based estimation, the Bayesian approach completely captured the joint parameter uncertainty and uncertainty about complicated functions of the parameters, such as the half-life measure of persistence based on generalized impulse response functions. Again, model comparison was made through marginal likelihoods, which reflects the relative abilities of models to predict the data given prior beliefs about model parameters. The empirical results for real exchange rate data from the G7 countries suggested a general support for nonlinearity, with the strength of the evidence depending on which country pair was being considered. They also found that model-averaged estimates of half-lives are almost always as small or smaller for the linear models alone, signifying that the purchasing power parity persistence conundrum is less of a conundrum than previously thought.

In the context of South Africa, Serenis and Tsounis (2014) examined the effect of exchange rate volatility for a set of three African countries: Malawi, Morocco and South Africa to aggregate exports during the period: 1973Q1-1990Q1. It was claimed that exchange rate volatility causes a reduction on the overall level of trade. Empirically, researchers often utilize the standard deviation of the moving average of the logarithm of the exchange rate as a measure of exchange rate fluctuation. Results from Serenis and Tsounis (2014) suggested significant negative effects from volatility on exports for the three countries when a measure of unexpected fluctuation was used. Bah and Amusa (2003) used the autoregressive conditional heteroskedastic (ARCH) and general ARCH $(\mathrm{GARCH})$ models to investigate the influence of the real exchange rate volatility on South Africa's export to its largest, single-nation trading partner - the United States (USA). The 
results indicated that volatility of the Rand's real exchange rate exerts a significant and negative effect on exports in both the long and short-run, while weakening in real exchange rates has a positive impact on exporting activity. Therefore, a stable competitive exchange rate and sound macroeconomic fundamentals that enhance international competitiveness are necessary to ensure greater market penetration of South Africa's exports. Chinzara (2011) examined the macroeconomic uncertainty and conditional stock market volatility in South Africa by conducting a review on the literature dealing with the effects of exchange rate volatility on trade, obtaining results that were sensitive to the choices of sample period, model specification, proxies for exchange rate volatility and countries considered. His results indicate that increased exchange rate volatility inhibits the growth of foreign trade.

It is clear from the above mentioned studies that the influence of nonlinearities and structural breaks, in the context of estimating persistence in volatility have been relegated to the background. We therefore intend to fill this gap by examining the levels of the South African rand exchange rates and their associated volatilities against a group of currencies in an expanded daily exchange rate dataset using fractional integration. The choice of the currencies was based on the trade relations between South Africa and the countries under analysis.

This paper takes a different perspective as far as exchange rates and their volatilities are concerned by taking nonlinearities and structural breaks into account. To a large extent, we seek to examine long memory and also the degree of persistence of exchange rate levels and their volatilities, using in the latter case the squared returns as a proxy for the volatility. The rest of paper is organised as follows: Section 2 presents a review of the history of the exchange rates in South Africa; Section 3 briefly explains the 
modelling of exchange rates; Section 4 focuses on the data and the methodology used in the paper; Section 5 presents the results, while Section 6 shows some concluding remarks.

\section{Exchange rates in South Africa}

The revolutionary works of Edward (1989), Ghura and Grennes (1993), Obadan (1994), Mkenda (2001), Miyakoshi (2003), Joyce and Kamas (2003), among others, expressed their views on exchange rates determinants and behaviour. For instance, Edward (1989) found that in the long run, only real variables will affect the stability of real exchange rates in a panel of twelve countries including South Africa. Nevertheless, real and nominal factors were found to be significant in driving exchange rates in the short run with no specific results for South Africa. Exchange rate determination can either be left to the forces of demand and supply or can be managed by the authorities. In one extreme, a country can implement a freely floating exchange rate system where the value of the currency is determined by the market forces of demand and supply. In this system, the authorities do not interfere in the foreign exchange market. This system (of a freely floating exchange rate system) is not practiced by any country in the world. In the other extreme, monetary authorities may adopt a fixed exchange rate system. The fixed exchange rate system is still being employed by some countries such as Argentina and Estonia.

There have been many exchange rate regimes in South Africa since the end of Breton Woods System (Van der Merwe, 1996, 2005). These include (a) a stage of direct monetary controls and the desire to sustain the stability of the rand exchange rate during the 1970s; (b) a swing to more market-oriented measures and the implementation of money supply targets in the 1980s; (c) the era of easy-going inflation targeting and 
managed floating of the rand in the 1990s; and (d) the official adoption of inflation targeting and a floating exchange rate regime in February 2000.

The first chapter is the period that was linked to the Bretton Woods System of fixed exchange rates in the 1970s. To begin with, the South Reserve Bank (SARB) devalued the rand and pegged it against the US dollar since the domestic market could not support a free-floating exchange rate system due to the underdeveloped nature of the foreign exchange market (Steyn, 2004). Nonetheless, an "independent managed floating" exchange rate system was adopted in June 1974 to mirror the changes in the market rate of the ZAR/USD exchange, the essential balance of payments and domestic economic conditions. There were speculative attacks on the rand, which forced the authorities to change the exchange rate policy in June 1975 in favour of a ZAR/USD exchange rate. The rand moved with the dollar for long periods under restrictive control measures. A heavy reliance was placed on exchange controls, which deterred the inflow of foreign capital. Authorities saw this as an ineffective way of allocating the available foreign exchange, which led to the abandonment of this policy framework. Consequently, the authorities decided to implement more market-oriented measures and monetary targeting.

The status quo changed dramatically after the formation of the government of national unity in 1994, and the country became reintegrated in the world economy and in the global financial market. Accordingly, the monetary authorities begun to remove virtually all exchange rate restrictions. This policy was largely successful and hence paved way for the official adoption of inflation targeting and a floating exchange rate system in February 2000. Increasing food prices due to declining agricultural output, decreasing manufacturing output, volatility in the exchange rate of the ZAR/USD and low domestic growth, among others, pose serious challenges to monetary policy actions. Coupled with the performance of the informal inflation targeting prior to February 
2000 , this forced the monetary authorities to adopt inflation targeting to further tighten three monetary policies. The authorities targeted 3-6\% Consumer Price Index (CPIX) inflation to be achieved by the end of 2002. This policy has been largely successful and the monetary authorities have decided to continue to apply the framework consistent with their mandate of price stability and a stable exchange rate system, this being the final monetary policy framework.

\section{A short review of exchange rates modelling}

Forecasting exchange rate movements has always been an attractive issue in international finance literature. Hence, there is a vast amount of literature on both theoretical and empirical fronts, especially regarding the determination of exchange rates, mostly for developed economies. For developing economies however, the literature on the determination of exchange rate movements is virtually non-existent, in particular those discussing persistence in exchange rate volatility. From a theoretical point of view, the literature on exchange rates movements can be classified into two main categories namely the chartists and the fundamentalists. The chartists consist of those studies whose models based their expectations on exchange rate fluctuations on its past movements, whereas fundamentalists encompass those studies that hinge on purely the fundamentals, so that when the exchange rate is driven away from the fundamentals they form expectations that it will return in due course to the levels projected by the fundamentals. (Argy, 1994). Most of the research that has been conducted to date regarding floating exchange rates tends to concentrate more on the fundamentals. Floating exchange rate models based on fundamentals are classified into two categories namely monetary and portfolio balance models. According to Neely and Sarno (2002), the monetary models of exchange rates can be further subdivided into two groups- the flexible-price model 
(Frankel, 1976; Bilson, 1978a,b and Mussa,1976, 1979) and the sticky-price model (Dornbucsh, 1976 and Frankel, 1979). Etuk (2012) conducted a study on the exchange rate nexus between the Naira-US Dollar using an ARIMA-SARIMA model and found some seasonal effects between the two currencies. In another study, Li et al. (2011) examined the monthly seasonality of foreign exchange $(\mathrm{FX})$ returns for eight major currencies (against the US dollar) from 1972 to 2010, and found that five currencies exhibited significantly higher returns in the month of December and a significant reversal in January. This result was contrary to previous research which focused largely on the daily patterns within FX returns. Evans and Tawiah (2015) also looked at the effects of seasonality of Ghanaian economic activities such as agriculture, consumption, on the Cedi - US Dollar exchange using ARIMA and X-12 models. It was found in the paper that depreciation of the Ghana cedi to the dollar followed a moving seasonality with a constantly repeating year to year pattern. Takaendesa (2006), using a VAR model, investigated the main determinants of the real exchange rate and the dynamic adjustment of exchange rates following shocks to those determinants, using quarterly South African data for the period $1975-2005$. He found that terms of trade, domestic credit and openness are the only significant variables when explaining the variation in the real exchange rate.

Giot et al (2010) examined the relationship between volume and realized volatility. In contrast to prior studies, they decomposed realized volatility into two major components: a continuously varying component and a discontinuous jump component. Their results confirmed that the amount of trade is the dominant factor shaping the volume volatility relation, whatever volatility component is considered.

From the aforementioned models, it is clear that the incorporation of issues such as fractional integration, structural breaks and nonlinearities in determining the 
movements in the exchange rates in South Africa is underwhelming, hence the need to conduct this study.

\section{Data and methodology}

We use daily data corresponding to the South African rand against the US dollar, the British pound, the Euro, the Japanese yen, the Chinese yuan, the Australian dollar, and the Botswana Pula, obtained from the Reserve Bank of South Africa (SARB) website (www.resbank.co.za), for the time period from January 4, 2010 until November 27, 2018. See,

https:/www.resbank.co.za/Research/Rates/Pages\SecelectedHistoricalExchangeAndInte restRates.aspx

We use these currencies because they refer to the countries with the highest trading relationships with South Africa. Figure 1 displays the time series plots.

\section{[Insert Figure 1 and Table 1 about here]}

Table 1 displays some descriptive statistics. We observe that the economies with the lowest mean exchange rates are Australia (0.111), China (0.641) and Botswana (0.844), while the country with the highest mean exchange rate is Japan (96163.123). We also observe that Japan presents the highest standard deviation and China the lowest one. This means that Japan is the most volatile country within this group while China is the least one.

We use fractional integration methods. The idea behind this concept is that the number of differences required in a series to render it stationary $\mathrm{I}(0)$ may not necessarily be an integer number but any real one, including thus fractional values. We say that a process $\left\{\mathrm{x}_{\mathrm{t}}, \mathrm{t}=0, \pm 1, \ldots\right\}$ is integrated of order $\mathrm{d}$, and denoted as $\mathrm{x}_{\mathrm{t}} \approx \mathrm{I}(\mathrm{d})$ if it can be represented as: 


$$
(1-L)^{d} x_{t}=u_{t}, \quad t=1,2, \ldots
$$

where $\mathrm{L}$ is the lag operator $\left(\mathrm{Lx}_{\mathrm{t}}=\mathrm{x}_{\mathrm{t}-1}\right)$ and $\mathrm{u}_{\mathrm{t}}$ is $\mathrm{I}(0)$ indicating a covariance stationary process with a spectral density function that is positive and bounded at all frequencies in the spectrum.

In the context of $\mathrm{I}(\mathrm{d})$ models, the estimation of the differencing parameter $\mathrm{d}$ is crucial. Thus, if $d=0, x_{t}$ is short memory or $I(0)$, while $d>0$ implies long memory behaviour, so-named because of the strong degree of association between observations far distant in time. From a statistical viewpoint, 0.5 is another relevant value: if $d<0.5$, $\mathrm{x}_{\mathrm{t}}$ is covariance stationary, while $\mathrm{d} \geq 0.5$ implies nonstationary (in the sense that the variance of the partial sums increases in magnitude with d); finally, from an economic viewpoint $\mathrm{d}=1$ is also relevant: $\mathrm{d}<1$ indicates mean reversion, with shocks disappearing in the long run, while $\mathrm{d} \geq 1$ shows a lack of mean reversion with shocks persisting forever. Therefore, the parameter $d$ is very important to determine the degree of persistence in the data, and higher the value of $d$ is, the higher the degree of persistence is, or alternatively, the lower the value of $d$ is, the faster the convergence process of a series is to its original level after a shock.

We estimate the differencing parameter, $d$, by using both parametric and semiparametric techniques. Dealing with the parametric methods we use the Whittle function in the frequency domain as proposed in Dahlhaus (1989) and implemented through the tests of Robinson (1994). Semiparametric methods, based on local Whittle methods (Robinson, 1995, Shimotsu and Phillips, 2006; Abadir et al., 2007) will also be employed in the paper. 


\section{Empirical results}

This section is divided in two parts, one dealing with the levels (i.e. exchange rates) and the other dealing with their associated volatilities, measured in terms of both absolute returns and squared returns. These two measures have been widely employed in the literature to approximate the volatility of the processes. Absolute returns have been employed in Ding et al. (1993), Granger and Ding (1996), Bollerslev and Wright (2000), Gil-Alana (2005), Sibbertsen (2004), Cotter (2005), Giles (2008) and Yang and Perron (2010) among many others. On the other hand, squared returns were used in Lobato and Savin (1998), Blair et al. (2001), Gil-Alana (2003), Cotter (2005), Patton (2011), Jondeau (2015), etc.

\section{5a. Exchange rates in levels}

The first thing we do in this section is to look at the level of the observed data, focussing on the degree of persistence by using fractional integration. Thus, the estimated model is the following one:

$$
\mathrm{y}_{\mathrm{t}}=\beta_{0}+\beta_{1} t+x_{\mathrm{t}} ; \quad(1-L)^{d} x_{t}=u_{t}, \quad t=0,1, \ldots
$$

where $y_{t}$ refers to each of the time series we observe, $\beta_{0}$ and $\beta_{1}$ are unknown coefficients referring respectively to the intercept and a linear time trend; $x_{t}$ is supposed to be $I(d)$ and thus, $u_{t}$ is $I(0)$, and $d$ is a real value that is estimated from the data along with the other parameters in the model.

Table 2 displays the estimates of $d$ and their associated $95 \%$ confidence bands, in the model given by (2) under the assumption that $u_{t}$ is a white noise process. We display the results for both the original data and the log-transformed data, and present the results for two cases: i) including an intercept, and ii) with an intercept and a linear time trend, marking in bold in the table the selected model for each case. We see that most of the 
values are around 1. In fact, the unit root null hypothesis cannot be rejected in five out of the seven exchange rates examined. The only evidence against the I(1) case is found in the cases of Botswana and Japan where the estimated value of $\mathrm{d}$ is found to be slightly below 1 , and the unit root null is rejected in favour of mean reversion $(\mathrm{d}<1)$. This happens using both original and logged data.

\section{[Insert Tables 2 and 3 about here]}

Table 3 presents the results for the case of autocorrelated errors. The values are very similar to those with uncorrelated errors in the sense that all them are very close to 1. However, evidence of mean reversion takes place now for Bostwana, China and USA with the original data, and for Australia and USA with the logged-transformed data. Nevertheless, even in these cases the estimated values of $d$ are very large and close to 1 indicating a large degree of persistence.

Next we estimate $d$ using a semiparametric approach where no functional form is imposed on the error term. We use here a "local" Whittle estimated in the frequency domain, as initially proposed by Robinson (1995) and later extended and improved by Velasco (1999), Shimotsu and Phillips (2006), Abadir et al. (2007) and others. We use Robinson (1995) rather than these other methods since these require additional chosenuser parameters, and the results will be then sensitive to the choice of these values. ${ }^{1}$

\section{[Insert Table 4 about here]}

Table 4 displays the estimated values of $\mathrm{d}$ for a selected group of bandwidth numbers, $\mathrm{T}^{\mathrm{m}}$, with $\mathrm{m}=0.30,0.35, \ldots, 0.60 .^{2} \mathrm{We}$ see that most of the estimates are around 1 , and evidence of mean reversion is only found in a couple of cases for Japan and Australia with the original data, and for Japan with the logged ones.

\footnotetext{
${ }^{1}$ Given the nonstationary nature of the series under the study, the analysis was conducted in first differenced data, adding then the value of 1 to the estimated value of $d$.

2 These values are those usually employed in most empirical applications
} 
We also look at the possibility of structural breaks. This is a very relevant issue, noting that many authors argue that fractional integration might be an artificial artifact generated by the presence of breaks which have not been taken into account (Diebold and Inoue, 2001; Granger and Hyung, 2004; Ben Nasr et al., 2014; etc.). We conduct two approaches here: Bai and Perron (2003) and Gil-Alana (2008), the latter one being an extension of the former to the fractional case. The results were identical with the two methods, and four breaks were found in each series. (See Table 5).

Most of the breaks take place at around 1) August and September 2011;2) May and December 2013; 3) April and October 2015; and 4) April and December 2016. These significant dates may probably be related with the introduction of the Technical Economic Cooperation Programs (ITEC) which took place after South Africa was admitted as a BRICS member.

\section{[Insert Tables 5 and 6 about here]}

In Table 6 we have re-estimated the value of $d$ for each subsample in each series, obtaining evidence of mean reversion (i.e., $\mathrm{d}<1$ ) in some cases. In particular, for most of the rates, namely those of Australia, China, the Euro, the UK and the US, the estimated value of $\mathrm{d}$ is significantly smaller than 1 for only the third subsample; for Japan, mean reversion is detected in the first and third subsamples, and for Botswana in the first four subsamples, and these results hold in both the original and the log-transformed data. Thus, according to these results, mean reversion in the exchange rates with respect to most countries only take place during the period between 2013 and 2015, and in the case of Botswana, in all cases except for the last period starting at 2017.

As a final analysis within this subsection based on the level of the exchange rates, we also examine the possibility of non-linearities in the data, and for this purpose, we use 
the methodology developed in Cuestas and Gil-Alana (2016), which is based on the Chebyshev's polynomials in time. In particular, we examine now the following model,

$$
y_{t}=\sum_{i=0}^{m} \theta_{i} P_{i T}(t)+x_{t}, \quad(1-L)^{d} x_{t}=u_{t}, \quad t=1,2, \ldots
$$

where $\mathrm{P}_{\mathrm{i}}$ are the Chebyshev time polynomials defined by:

$$
\begin{gathered}
\mathrm{P}_{0, \mathrm{~T}}(\mathrm{t})=1, \\
P_{i, T}(t)=\sqrt{2} \cos (i \pi(t-0.5) / T), \quad t=1,2, \ldots, T ; \quad i=1,2, \ldots,
\end{gathered}
$$

where $\mathrm{m}$ indicates the degree of non-linearity. Thus, if $m=0$ the model contains an intercept, if $m=1$ it adds a linear trend, and if $m>1$ the model becomes non-linear, and the higher $m$ is the less linear the approximated deterministic component becomes. ${ }^{3}$

To allow for some degree of nonlinearity we suppose $m=3$ and if $\theta_{2}$ and/or $\theta_{3}$ are statistically significant we obtain evidence of non-linearities in the data. Results are displayed in Table 7 , and we observe that only $\theta_{2}$ is significant in the case of China. The rest of the non-linear coefficients are all insignificant providing no evidence of non-linear behaviour, at least of the form examined here.

\section{5b. Exchange rates in volatility}

This section deals with the analysis of persistence in the volatility, measured in terms of both absolute and squared returns. Table 8 displays some descriptive statistics on the two variables. The country with the highest mean absolute returns is Japan (0.008) and the economy with the least value is Botswana (0.003). Looking at the squared returns, the highest values are those of the UK (0.0052), US (0.0039) and China (0.0039) and the lowest one is Botswana (0.0011).

\footnotetext{
${ }^{3}$ Hamming (1973) and Smyth (1998) contain a detailed description of these polynomials.
} 


\section{[Insert Table 8 about here]}

Tables 9 and 10 displays the estimates of d respectively for the two cases of uncorrelated and autocorrelated errors. The first thing we observe is that the estimates are all significantly positive, providing evidence of long memory and persistence in the volatility processes. For the absolute returns, the estimates range between 0.12 and 0.17 with no autocorrelation, and they are slightly higher (ranging between 0.16 and 0.20 ) with autocorrelation. Using the squared returns, there is higher dispersion, and the values range between 0.09 (UK) and 0.22 (Botswana) under no autocorrelation, and between 0.05 (Botswana) and 0.16 (China) with autocorrelation.

\section{[Insert Tables 9 - 11 about here]}

Finally, the semiparametric (Whittle) approach of Robinson (1995) is also implemented on the transformed return series, and the estimated values of $d$ are reported across Table $11 .^{4}$ We observe that all of them are significantly higher than 0 , once more showing long memory, and ranging now between 0.248 and 0.500 with the absolute returns, and between 0.179 and 0.500 with the squared returns.

\section{Conclusions}

In this paper we have examined the dynamic structure of the exchange rates in South Africa by using fractionally integrated methods. For this purpose, we have used the daily structure of the South African rand against seven related currencies, namely the US dollar, the British pound, the Euro, the Japanese yen, the Chinese yuan, the Australian dollar and the Botswana Pula.

The analysis was conducted using both levels and volatilities. For the level, we use the original and the log-transformed data, while volatility was approximated by using

\footnotetext{
${ }^{4}$ Using Shimotsu and Phillips (2006) and Abadir et al. (2007) produced essentially the same results.
} 
absolute and squared returns, measuring this as the first differences of the logged series. Starting with the levels, we observe that most of the estimated values of $d$ were around 1 , implying I(1) behaviour, and though some degree of mean reversion is found in some cases, the values of $\mathrm{d}$ are very close to 1 , indicating a large degree of persistence. The possibility of structural breaks was also examined, and two breaks were found in each of the series, in most cases at times related to the introduction of the Technical Economic Cooperation Programs (ITEC) which was after South Africa had been admitted as a BRICS member. Looking at the orders of integration at each of the subsamples in each series we observe that mean reversion is only found in the subseries constrained between 2013 and 2015 in all cases except Botswana; for the latter country mean reversion takes place in all subsamples except for the last period starting at 2017. Testing for the possibility of non-linearities and using Chebyshev's polynomial in time, we find only little evidence in the case of China.

Looking at the volatility, measured in terms of the absolute and squared returns, evidence of long memory patterns is detected in all cases with the estimated values of $d$ ranging in the stationary region $(0<\mathrm{d}<0.5)$. This is consistent with many other empirical studies conducted in developed countries such as Gil-Alana (2000), Benigno (2004), Caporale and Gil-Alana (2004), among others. The indication of persistence and nonmean reversion behaviour discovered in the various exchange rates series considered in this study implies that shocks will, in general, have permanent effects. The implication of this is that monetary policymakers and government may consider passing a new monetary policy or tightening the existing monetary policy, in order to control the rand in the face of the volatilities of other currencies. Moreover, our measures of persistence in exchange rates volatilities allow us to establish cross-country comparisons, and it is deduced that 
significant differences arising between these countries, may be related to the different monetary institutions governing each of them. 


\section{References}

Abadir, K.M., W. Distaso and L. Giraitis 2007, 'Nonstationarity-extended local Whittle estimation', Journal of Econometrics 141, 1353-1384.

Bah, I. and H.A. Amusa (2003), Real exchange rate volatility and foreign trade: evidence from South Africa's exports to the United States, African Finance Journal, 5, 2, 1 - 20.

Bai, J. and P. Perron (2003), Computation and analysis of multiple change models Journal of Applied Econometrics 18, 1 - 22.

Ben Nasr, A., A.N. Ajmi and R. Gupta. (2014), Modelling the volatility of the Dow Jones Islamic market world index using a fractionally integrated time varying GARCH (FITVGARCH) model. Applied Financial Economics, 24: 993 - 1004.

Benigno, P. (2004), Real exchange rate persistence and monetary policy rules, Journal of Monetary Economics, 51, 3, 473 - 502.

Bilson, J. (1978a), The Monetary Approach to the Exchange Rate: Some Empirical Evidence, IMF Staff Papers 25, 1, 48 - 75.

Bilson, J., (1978b), Rational expectations and the exchange rate, in: Jacob Frenkel and Harry Johnson, eds., The Economics of Exchange Rates, 75 - 96.

Blair, B., S-H. Poon and S.J. Taylor, (2001), Forecasting S\&P 100 volatility. The incremental information content of implied volatilities and high frequency index returns, Journal of Econometrics, 105, 5 - 26.

Bollerslev, T. and J.H. Wright, (2000), High frequency data, frequency domain inference and volatility forecasting, Review of Economics and Statistics, 83, 596 - 602.

Caporale G.M. and L.A. Gil-Alana, (2004), Fractional cointegration and real exchange rates, Review of Financial Economics 13, 327 - 340.

Caporale, G. M. and L.A. Gil-Alana (2013), Long Memory and Fractional Integration in High Frequency Data on the US Dollar/British Pound Spot Exchange Rate, CESifo Working Paper Series No. 4224.

Chinzara, Z. (2011), Macroeconomic uncertainty and conditional stock market volatility in South Africa, SAJE South African Journal of Economics, 79, 1, 27-49.

Cotter, J., (2005), Uncovering long memory in high frequency UK futures, European.

Cuestas, J.C. and L.A. Gil-Alana, (2016), A Non-Linear Approach with Long Range Dependence Based on Chebyshev Polynomials, Studies in Nonlinear Dynamics and Econometrics, 20, 1, 57 - 74.

Dahlhaus, R. (1989) Efficient Parameter Estimation for Self-Similar Process. Annals of Statistics, 17, 1749 - 1766. 
Diebold F.X. and A. Inoue (2001), Long memory and regime switching. Journal of Econometrics, 105, 131 - 159.

Ding, Z., Granger, C.W.J., and Engle, R.F., (1993), A long memory property of stock markets and a new model, Journal of Empirical Finance, 1, 83 - 106.

Dormbusch (1976), Expectations and Exchange Rate Dynamics, Journal of Political Economy, Vol. 84, No. 6 (Dec., 1976), 1161 - 1176.

Edwards, S. (1989), Real Exchange Rates in the Developing Countries: Concepts and Measurement, NBER Working Paper No. 2950, 1 - 52.

Etuk, E. H. (2012), Forecasting Nigerian Naira-US Dollar Exchange Rates by A Seasonal Arima Model. American Journal of Scientific Research, 59, 71 - 78.

Evans, B. and V. Tawiah, (2015), Seasonality of Exchange Rates in Ghana, International Journal of Research in Economics and Social Sciences (IJRESS), 5, 3.

Frenkel, J. A. (1976), On the Mark: A Theory of Floating Exchange Rates Based on Real Interest Differentials, American Economic Review, 69, 610-622.

Frenkel, J. A. (1976), A Monetary Approach to the Exchange Rate: Doctrinal Aspects and Empirical Evidence, The Scandinavian Journal of Economics, 78, 2, 200 - 224.

Ghura, D. and T. Grennes, (1993), The real exchange rate and macroeconomic performance in Sub-Saharan Africa, Journal of Development Economics, 42, 1, 155 174.

Giot, P., Laurent, S. and Petitjean, M. (2010), Trading activity, realized volatility and jumps, Journal of Empirical Finance, Volume 17, Issue 1, Pages 168-175

Gil-Alana, L.A., (2000), Mean reversion in the real exchange rates, Economics Letters, $69,3,285-288$.

Gil-Alana, L.A., (2004), Fractional integration in the volatility of asset returns, European Review of Economics and Finance 2, 41 - 52.

Gil-Alana, L.A., (2005), Long memory in daily absolute and squared returns in the Spanish stock market, Advances in Investment Analysis and Portfolio Management 1, 198-217.

Gil-Alana, L. A. (2008), Fractional integration and structural breaks at unknown periods of time. Journal of Time Series Analysis, 29: 163 - 185.

Giles, D.E., (2008), Some properties of absolute returns as a proxy for volatility, Applied Financial Economic Letters, 4, 5, 347 - 350.

Granger, C.W.J., and Z. Ding, (1996), Varieties of long memory models, Journal of Econometrics, 73, $61-78$. 
Granger C.W.J and N. Hyung, (2004), Occasional structural breaks and long memory with an application to the S\&P 500 absolute stock returns. Journal of Empirical Finance, $11,399-421$.

Hamming, R.W. (1973), Numerical Methods for Scientists and Engineers, Dover.

Jondeau, E. (2015), The dynamics of squared returns under contemporaneous aggregation of GARCH models, Journal of Empirical Finance, 32, 80 - 93.

Joyce, J. and L. Kamas (2003), Real and nominal determinants of real exchange rates in Latin America: Short-run dynamics and long-run equilibrium, Journal of Development Studies 39, 6, 155 - 182

Lo, M.C. and J. Morley (2015), Bayesian analysis of nonlinear exchange rate dynamics and the purchasing power parity persistence puzzle, Journal of International Money and Finance 51, $285-302$

Lobato, I.N. and N.E. Savin, 1998, Real and spurious long memory properties of stock market data, Journal of Business and Economic Statistics 16, 261 - 268.

Li, Bin, Liu, Benjamin, Bianchi, Robert, Su, Jen-Je (2011), Monthly Seasonality in Currency Returns: 1972-2010, JASSA The Finsia Journal of Applied Finance Issue 3.

Miyakoshi (2003), Real and nominal determinants of real exchange rates in Latin America: Short-run dynamics and long-run equilibrium, Journal of Development Studies $39,6,155-182$

Mkenda, B. K. (2001), Is East Africa an Optimum Currency Area? Working Papers in Economics no 41 April 2001, Department of Economics Göteborg University, 1 - 51.

Mussa, M. (1976), The Exchange Rate, the Balance of Payments and Monetary and Fiscal Policy under a Regime of Controlled Floating, Scandinavian Journal of Economics 78, 2, $229-48$

Mussa, M. (1979), Empirical regularities in the behaviour of exchange rates and theories of the foreign exchange market, Carnegie-Rochester Conference Series on Public Policy $11,1,9-57$.

Neely, C. and L. Sarno, (2002), How well do monetary fundamentals forecast exchange rates?, Economic Research Reserve Federal Bank of St. Louis Review, 84, 5, 74.

Obadan, M. I. (1994), Real Exchange Rates in Nigeria: A Preliminary Study. NCEMA Monograph Series, No. 6

Patton, A, J, (2011), Volatility forecast comparison using imperfect volatility proxies, Journal of Econometrics 160, 1, 246 - 256.

Robinson, P.M. (1994), Efficient tests of nonstationary hypotheses, Journal of the American Statistical Association 89, 1420 - 1437. 
Robinson, P.M. (1995), Gaussian semi-parametric estimation of long range dependence, Annals of Statistics 23, 1630-1661.

Sauer, C. and Bohara, A. (2001), Exchange Rate Volatility and Exports: Regional Differences between Developing and Industrialized Countries, Review of International Economics, 91, 133 - 152.

Source of Data: South African Reserve Bank: Monthly USD-ZAR, GBR-ZAR, EURZAR, AUT USD-ZAR, Pula-ZAR, JPN Yen-ZAR, and China Yuan-ZAR, monthly data January 1995 to December 2014, Accessed date: 23 August, 2017.

Serenis, D. and Tsounis, N., (2014), Does Exchange Rate Variation Effect African Trade Flows? Procedia Economics and Finance, 14, 565 - 574.

Shimotsu, K. and P.C.B. Phillips, (2006). Local Whittle estimation of fractional integration and some of its variants. Journal of Econometrics, 130, 209 - 233.

Sibbertsen, P., (2004), Long memory in volatilities of German stock returns, Empirical Economics, 29, 477 - 488.

Smyth, G.K., (1998), Polynomial Aproximation, John Wiley \& Sons, Ltd, Chichester, 1998.

Tenrehyro (2007), On the trade impact of nominal exchange rate volatility, Journal of Development Economics, 82, 485-508.

Takaendesa, P. (2006). The behaviour and fundamental determinants of the real exchange rate in South Africa (Doctoral dissertation, Rhodes University).

Van der Merwe, E. J. (1996), Exchange rate management policies in South Africa: Recent experiences and prospects. Occasional Paper no. 9. Pretoria: South African Reserve Bank.

Van der Merwe, E.J. (2005). The exchange rate regime and monetary arrangements in South Africa. Chapters, pp. 1-42.

Yang K. L. and P. Perron' (2010), Modeling and forecasting stock return volatility using a random level shift model, Journal of Empirical Finance, 17, 1138 - 156. 
Figure 1: Time series plots

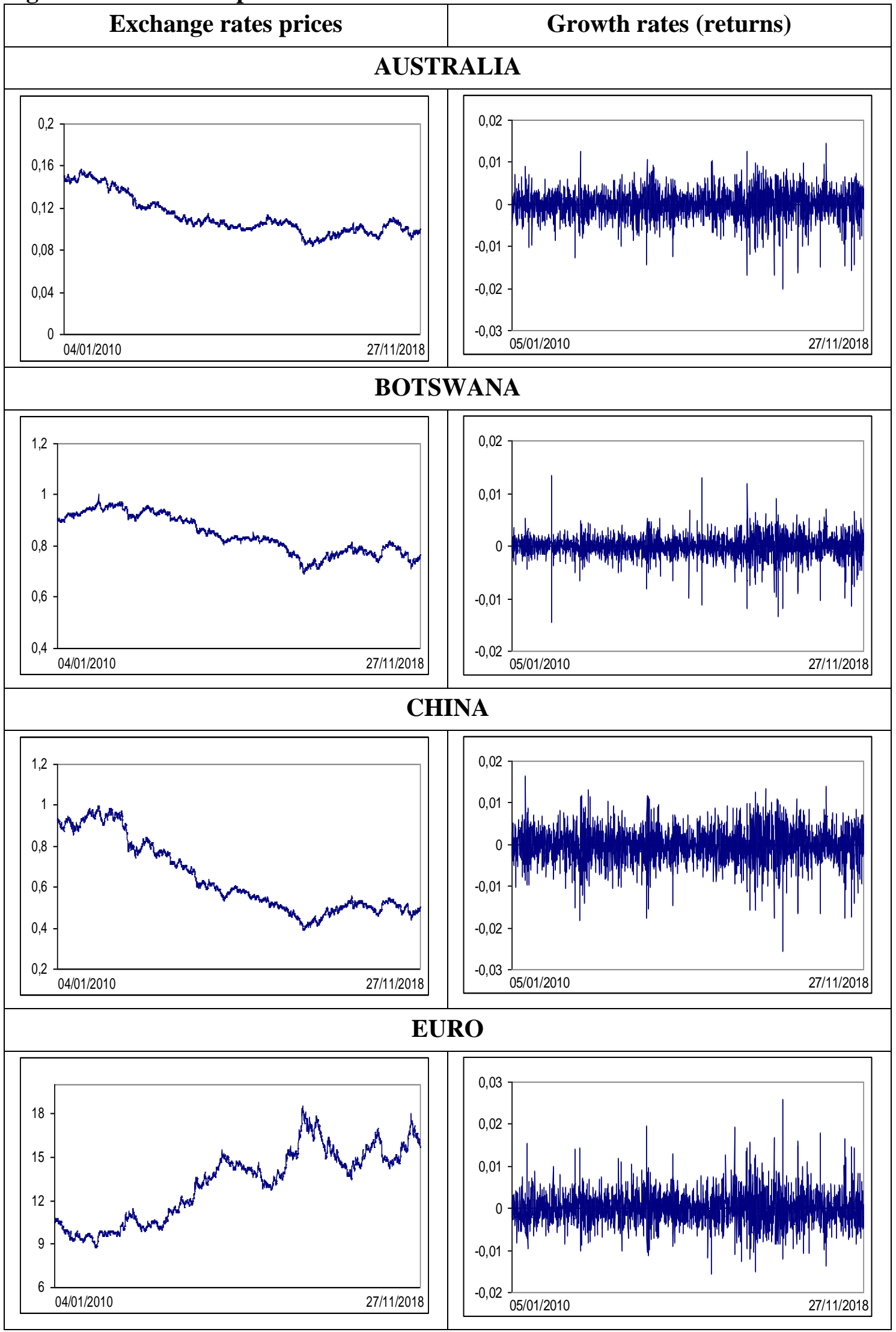


Figure 1: Time series plots (cont.)

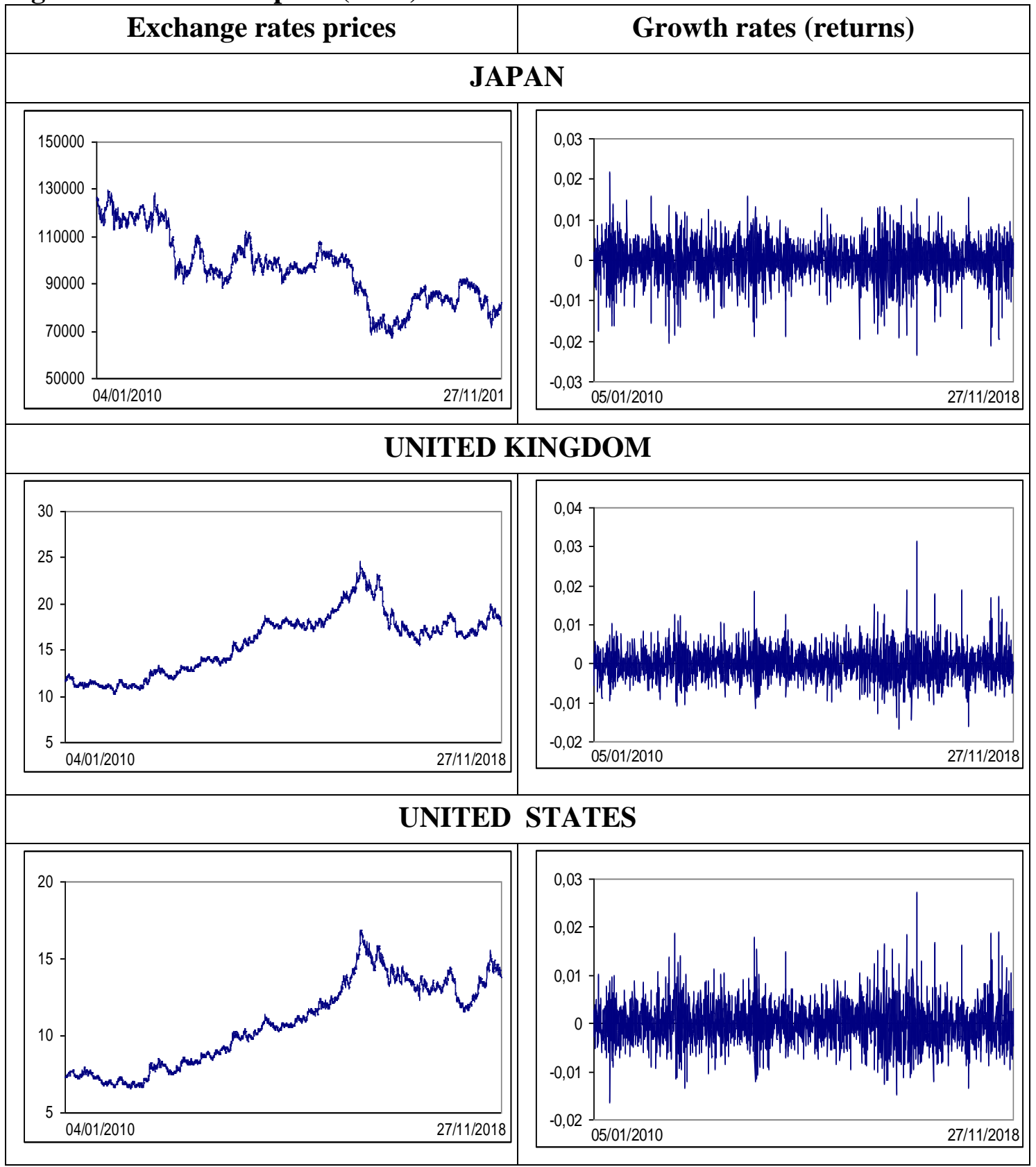


Table 1: Descriptive statistics_Levels

\begin{tabular}{|c|c|c|c|c|}
\hline \multicolumn{5}{|c|}{ i) Original data } \\
\hline Country & Mean & Std. Deviation & Max. value & Min. value \\
\hline Australia & 0.11195824 & 0.01817615 & 0.1572 & 0.0836 \\
\hline Botswana & 0.84410346 & 0.07556261 & 1.0048 & 0.6936 \\
\hline China & 0.64123673 & 0.17489824 & 0.9968 & 0.3895 \\
\hline Euro & 13.1578959 & 2.48254606 & 18.5288 & 8.7648 \\
\hline Japan & 96163.1235 & 14364.2796 & 129918 & 67336 \\
\hline U.K. & 15.8939192 & 3.31382851 & 24.5257 & 10.2557 \\
\hline U.S.A. & 10.7816579 & 2.74800664 & 16.8927 & 6.5962 \\
\hline \multicolumn{5}{|c|}{ ii) Logged transformed data } \\
\hline Country & Mean & Std. Deviation & Max. value & Min. value \\
\hline Australia & -0.95631069 & 0.06665553 & -0.80354746 & -1.07779372 \\
\hline Botswana & -0.07536358 & 0.03897786 & 0.00207963 & -0.15889092 \\
\hline China & -0.20831986 & 0.11354473 & -0.00139197 & -0.40949254 \\
\hline Euro & 1.11106922 & 0.08495276 & 1.26784729 & 0.94274201 \\
\hline Japan & 1.97808525 & 0.06518708 & 2.11366933 & 1.82824731 \\
\hline U.K. & 1.19149609 & 0.09321849 & 1.38962141 & 1.01096531 \\
\hline U.S.A. & 1.01802485 & 0.11446138 & 1.22769907 & 0.81929382 \\
\hline
\end{tabular}


Table 2: Estimates of $d$ under the assumption of no autocorrelation

\begin{tabular}{|c|c|c|c|c|}
\hline & \multicolumn{2}{|l|}{ Original data } & \multicolumn{2}{|c|}{ Log-transformed data } \\
\hline & An intercept & A time trend & An intercept & A time trend \\
\hline Australia & $\begin{array}{c}0.97 \\
(0.94,1.01)\end{array}$ & $\begin{array}{c}0.97 \\
(0.94,1.01)\end{array}$ & $\begin{array}{c}0.97 \\
(0.94,1.00)\end{array}$ & $\begin{array}{c}0.97 \\
(0.94,1.00)\end{array}$ \\
\hline Botswana & $\begin{array}{c}0.92^{*} \\
(0.89,0.95) \\
\end{array}$ & $\begin{array}{c}0.91 \\
(0.89,0.95) \\
\end{array}$ & $\begin{array}{c}0.92^{*} \\
(0.89,0.95) \\
\end{array}$ & $\begin{array}{c}0.92 \\
(0.89,0.95) \\
\end{array}$ \\
\hline China & $\begin{array}{c}0.97 \\
(0.94,1.01)\end{array}$ & $\begin{array}{c}0.97 \\
(0.94,1.01)\end{array}$ & $\begin{array}{c}0.97 \\
(0.94,1.00)\end{array}$ & $\begin{array}{c}0.97 \\
(0.94,1.00)\end{array}$ \\
\hline Euro & $\begin{array}{c}0.98 \\
(0.95,1.02) \\
\end{array}$ & $\begin{array}{c}0.98 \\
(0.95,1.02) \\
\end{array}$ & $\begin{array}{c}1.00 \\
(0.96,1.03)\end{array}$ & $\begin{array}{c}1.00 \\
(0.96,1.03)\end{array}$ \\
\hline Japan & $\begin{array}{c}0.95^{*} \\
(0.92,0.99) \\
\end{array}$ & $\begin{array}{c}0.95 \\
(0.92,0.99) \\
\end{array}$ & $\begin{array}{c}0.96^{*} \\
(0.93,0.99) \\
\end{array}$ & $\begin{array}{c}0.96 \\
(0.93,0.99) \\
\end{array}$ \\
\hline U.K. & $\begin{array}{c}1.00 \\
(0.97,1.03) \\
\end{array}$ & $\begin{array}{c}1.00 \\
(0.97,1.03) \\
\end{array}$ & $\begin{array}{c}1.00 \\
(0.97,1.03) \\
\end{array}$ & $\begin{array}{c}1.00 \\
(0.97,1.03) \\
\end{array}$ \\
\hline U.S.A. & $\begin{array}{c}0.98 \\
(0.94,1.01) \\
\end{array}$ & $\begin{array}{c}0.98 \\
(0.94,1.01) \\
\end{array}$ & $\begin{array}{c}0.97 \\
(0.94,1.01) \\
\end{array}$ & $\begin{array}{c}0.97 \\
(0.94,1.01) \\
\end{array}$ \\
\hline
\end{tabular}

In bold the selected model in terms of the deterministic components. *: Evidence of mean reversion at the $5 \%$ level.

Table 3: Estimates of $d$ under the assumption of autocorrelation

\begin{tabular}{|c|c|c|c|c|}
\hline & \multicolumn{2}{|l|}{ Original data } & \multicolumn{2}{|c|}{ Log-transformed data } \\
\hline & An intercept & A time trend & An intercept & A time trend \\
\hline Australia & $\begin{array}{c}0.95 \\
(0.91,1.01)\end{array}$ & $\begin{array}{c}0.96 \\
(0.91,1.01)\end{array}$ & $\begin{array}{c}0.93 \\
(0.88,0.98)\end{array}$ & $\begin{array}{c}0.93^{*} \\
(0.88,0.98)\end{array}$ \\
\hline Botswana & $\begin{array}{c}0.94^{*} \\
(0.90,0.99)\end{array}$ & $\begin{array}{c}0.94 \\
(0.90,0.99)\end{array}$ & $\begin{array}{c}0.94 \\
(0.90,1.00)\end{array}$ & $\begin{array}{c}0.94 \\
(0.90,1.00)\end{array}$ \\
\hline China & $\begin{array}{c}0.96 \\
(0.91,0.99)\end{array}$ & $\begin{array}{c}0.96^{*} \\
(0.91,0.99)\end{array}$ & $\begin{array}{c}0.94 \\
(0.90,1.00)\end{array}$ & $\begin{array}{c}0.94 \\
(0.90,1.00) \\
\end{array}$ \\
\hline Euro & $\begin{array}{c}0.96 \\
(0.91,1.01) \\
\end{array}$ & $\begin{array}{c}0.96 \\
(0.91,1.01) \\
\end{array}$ & $\begin{array}{c}0.97 \\
(0.92,1.02) \\
\end{array}$ & $\begin{array}{c}0.97 \\
(0.92,1.02) \\
\end{array}$ \\
\hline Japan & $\begin{array}{c}0.96 \\
(0.91,1.02)\end{array}$ & $\begin{array}{c}0.96 \\
(0.91,1.02)\end{array}$ & $\begin{array}{c}0.97 \\
(0.92,1.01)\end{array}$ & $\begin{array}{c}0.97 \\
(0.92,1.01)\end{array}$ \\
\hline U.K. & $\begin{array}{c}1.00 \\
(0.94,1.05)\end{array}$ & $\begin{array}{c}1.00 \\
(0.94,1.05)\end{array}$ & $\begin{array}{c}0.98 \\
(0.94,1.04)\end{array}$ & $\begin{array}{c}0.98 \\
(0.94,1.04)\end{array}$ \\
\hline U.S.A. & $\begin{array}{c}0.95 \\
(0.89,0.99)\end{array}$ & $\begin{array}{c}0.95^{*} \\
(0.89,0.99)\end{array}$ & $\begin{array}{c}0.95 \\
(0.89,0.99)\end{array}$ & $\begin{array}{c}0.95^{*} \\
(0.89,0.99)\end{array}$ \\
\hline
\end{tabular}

In bold the selected model in terms of the deterministic components. *: Evidence of mean reversion at the $5 \%$ level. 
Table 4: Estimates of $d$ based on a semiparametric methods

\begin{tabular}{|c|c|c|c|c|c|c|c|}
\hline \multicolumn{8}{|c|}{ i) Original data } \\
\hline Country / m & $\mathrm{T}^{0.30}$ & $\mathrm{~T}^{0.35}$ & $\mathrm{~T}^{0.40}$ & $\mathrm{~T}^{0.45}$ & $\mathrm{~T}^{0.50}$ & $\mathrm{~T}^{0.55}$ & $\mathrm{~T}^{0.60}$ \\
\hline Australia & 0.884 & 0.940 & 1.230 & 1.107 & $0.873^{*}$ & 0.906 & 0.918 \\
\hline Botswana & 0.972 & 0.982 & 1.034 & 0.959 & 0.962 & 0.959 & 0.943 \\
\hline China & 1.148 & 0.959 & 1.029 & 0.964 & 0.951 & 0.940 & 0.935 \\
\hline Euro & 0.867 & 1.070 & 1.115 & 0.940 & 0.970 & 0.983 & 0.973 \\
\hline Japan & $0.664^{*}$ & 0.840 & 0.949 & $0.846^{*}$ & 0.896 & 0.906 & 0.934 \\
\hline U.K. & 1.165 & 1.220 & 1.098 & 0.953 & 0.937 & 0.985 & 0.972 \\
\hline U.S.A. & 0.904 & 0.966 & 0.971 & 0.941 & 0.998 & 0.973 & 0.937 \\
\hline Lower $95 \%$ & 0.752 & 0.787 & 0.824 & 0.854 & 0.880 & 0.900 & 0.918 \\
\hline Upper $95 \%$ & 1,247 & 1.212 & 1.175 & 1.145 & 1.119 & 1.099 & 1.081 \\
\hline \multicolumn{8}{|c|}{ ii) Logged transformed data } \\
\hline Country / m & $\mathrm{T}^{0.30}$ & $\mathrm{~T}^{0.35}$ & $\mathrm{~T}^{0.40}$ & $\mathrm{~T}^{0.45}$ & $\mathrm{~T}^{0.50}$ & $\mathrm{~T}^{0.55}$ & $\mathrm{~T}^{0.60}$ \\
\hline Australia & 0.813 & 0.899 & 1.237 & 1.121 & 0.883 & 0.920 & 0.925 \\
\hline Botswana & 0.935 & 1.015 & 1.030 & 0.948 & 0.962 & 0.966 & 0.948 \\
\hline China & 1.120 & 0.990 & 1.036 & 0.963 & 0.954 & 0.950 & 0.927 \\
\hline Euro & 0.975 & 1.103 & 1.115 & 0.977 & 0.975 & 0.978 & 0.968 \\
\hline Japan & $0.692^{*}$ & 0.899 & 0.980 & 0.876 & 0.921 & 0.927 & 0.943 \\
\hline U.K. & 1.180 & 1.080 & 1.054 & 0.972 & 0.923 & 0.972 & 0.954 \\
\hline U.S.A. & 0.992 & 0.950 & 0.983 & 0.959 & 0.982 & 0.964 & 0.934 \\
\hline Lower $95 \%$ & 0.752 & 0.787 & 0.824 & 0.854 & 0.880 & 0.900 & 0.918 \\
\hline Upper $95 \%$ & 1,247 & 1.212 & 1.175 & 1.145 & 1.119 & 1.099 & 1.081 \\
\hline
\end{tabular}

* and bold: Evidence of mean reversion $(\mathrm{d}<1)$ at the $5 \%$ level. 
Table 5: Break dates using Bai and Perron (2003)

\begin{tabular}{|c|c|c|}
\hline Country & Breaks & Break dates \\
\hline Australia & 4 & $20 / 09 / 2011 ; 02 / 01 / 2014 ; 26 / 10 / 2015 ; 24 / 02 / 2017$ \\
\hline Botswana & 4 & $05 / 07 / 2012 ; 04 / 11 / 2013 ; 12 / 08 / 2015 ; 08 / 12 / 2016$ \\
\hline China & 4 & $20 / 09 / 2011 ; 17 / 05 / 2013 ; 29 / 05 / 2015 ; 24 / 10 / 2016$ \\
\hline Euro & 4 & $19 / 09 / 2011 ; 22 / 05 / 2013 ; 24 / 08 / 2015 ; 21 / 12 / 2016$ \\
\hline Japan & 4 & $10 / 08 / 2011 ; 27 / 12 / 2012 ; 24 / 08 / 2015 ; 21 / 12 / 2016$ \\
\hline U.K. & 4 & $21 / 09 / 2011 ; 31 / 05 / 2013 ; 21 / 04 / 2015 ; 23 / 08 / 2016$ \\
\hline U.S.A. & 4 & $21 / 09 / 2011 ; 21 / 05 / 2013 ; 24 / 07 / 2015 ; 29 / 12 / 2016$ \\
\hline
\end{tabular}

Table 6: Estimated values of $d$ for each subsample

\begin{tabular}{|c|c|c|c|}
\hline Country & Sub-sample & Original data & Logged data \\
\hline \multirow{5}{*}{ Australia } & $1 \mathrm{st}$ & $0.96 \quad(0.90,1.03)$ & $0.96 \quad(0.90,1.03)$ \\
\hline & 2nd & $0.97 \quad(0.90,1.05)$ & $0.96(0.90,1.04)$ \\
\hline & $3 \mathrm{rd}$ & $0.89^{*}(0.84,0.96)$ & $0.89^{*}(0.83,0.96)$ \\
\hline & 4 th & $0.95 \quad(0.88,1.04)$ & $0.94 \quad(0.87,1.04)$ \\
\hline & 5th & $1.01(0.95,1.09)$ & $1.01(0.95,1.09)$ \\
\hline Country & Sub-sample & Original data & Logged data \\
\hline \multirow{5}{*}{ Botswana } & $1 \mathrm{st}$ & $0.92^{*}(0.87,0.98)$ & $\mathrm{0.93}^{*}(0.87,0.99)$ \\
\hline & 2nd & $0.87^{*}(0.80,0.96)$ & $0^{0.86}{ }^{*}(0.79,0.95)$ \\
\hline & $3 r d$ & $0.77^{*}(0.72,0.84)$ & $0.77^{*}(0.72,0.84)$ \\
\hline & 4th & $0^{0.89 *}(0.84,0.97)$ & $0.90^{*}(0.84,0.97)$ \\
\hline & 5 th & $0.98 \quad(0.92,1.05)$ & $0.98 \quad(0.92,1.05)$ \\
\hline Country & Sub-sample & Original data & Logged data \\
\hline \multirow{5}{*}{ China } & $1 \mathrm{st}$ & $0.97 \quad(0.91,1.05)$ & $0.98 \quad(0.91,1.05)$ \\
\hline & 2 nd & $0.95 \quad(0.87,1.05)$ & $0.95 \quad(0.87,1.05)$ \\
\hline & $3 r d$ & $0^{0.86}{ }^{*}(0.81,0.92)$ & $0.87^{*}(0.81,0.93)$ \\
\hline & 4th & $0.96 \quad(0.89,1.04)$ & $0.96 \quad(0.90,1.04)$ \\
\hline & 5 th & $1.00 \quad(0.93,1.07)$ & $1.00 \quad(0.93,1.07)$ \\
\hline Country & Sub-sample & Original data & Logged data \\
\hline \multirow{4}{*}{ Euro } & $1 \mathrm{st}$ & $1.09(1.02,1.19)$ & $1.09(1.02,1.18)$ \\
\hline & 2nd & $1.03(0.96,1.13)$ & $1.04(0.96,1.13)$ \\
\hline & $3 \mathrm{rd}$ & $\mathrm{0.93}^{*}(0.88,0.98)$ & $\mathrm{0.93}^{*}(0.88,0.98)$ \\
\hline & 4 th & $0.94 \quad(0.88,1.03)$ & $0.94 \quad(0.87,1.02)$ \\
\hline
\end{tabular}




\begin{tabular}{|c|c|c|c|}
\hline & 5 th & $1.03(0.96,1.11)$ & $1.02(0.96,1.11)$ \\
\hline Country & Sub-sample & Original data & Logged data \\
\hline \multirow{5}{*}{ Japan } & $1 \mathrm{st}$ & $0.88^{*}(0.81,0.96)$ & $0.88^{*}(0.81,0.96)$ \\
\hline & 2nd & $1.01 \quad(0.94,1.10)$ & $1.01(0.93,1.10)$ \\
\hline & $3 r d$ & $0.92^{*}(0.87,0.98)$ & $0.91^{*}(0.86,0.97)$ \\
\hline & 4 th & $0.95 \quad(0.89,1.03)$ & $0.95 \quad(0.88,1.03)$ \\
\hline & 5 th & $0.98 \quad(0.92,1.05)$ & $0.98 \quad(0.92,1.06)$ \\
\hline Country & Sub-sample & Original data & Logged data \\
\hline \multirow{5}{*}{ U.K. } & $1 \mathrm{st}$ & $1.08 \quad(1.01,1.17)$ & $1.08(1.01,1.17)$ \\
\hline & 2nd & $0.92(0.85,1.01)$ & $0.92(0.85,1.01)$ \\
\hline & $3 \mathrm{rd}$ & $0.91^{*}(0.85,0.98)$ & $0.91^{*}(0.85,0.98)$ \\
\hline & 4 th & $1.03(0.97,1.10)$ & $1.03(0.97,1.10)$ \\
\hline & 5 th & $0.99 \quad(0.93,1.06)$ & $0.99 \quad(0.93,1.06)$ \\
\hline Country & Sub-sample & Original data & Logged data \\
\hline \multirow{5}{*}{ U.S.A. } & $1 \mathrm{st}$ & $0.98 \quad(0.92,1.06)$ & $0.98 \quad(0.91,1.06)$ \\
\hline & 2nd & $0.93(0.85,1.03)$ & $0.93(0.85,1.02)$ \\
\hline & $3 r d$ & $0.85^{*}(0.79,0.92)$ & $0.85^{*}(0.79,0.91)$ \\
\hline & 4 th & $0.96(0.90,1.05)$ & $0.96 \quad(0.90,1.04)$ \\
\hline & 5 th & $1.03(0.97,1.11)$ & $1.03(0.97,1.11)$ \\
\hline
\end{tabular}

* and bold: Evidence of mean reversion $(\mathrm{d}<1)$ at the $5 \%$ level. 
Table 7: Estimated coefficients in a nonlinear model

\begin{tabular}{|c|c|c|c|c|c|}
\hline Country & $\mathrm{d}$ & $\theta_{1}$ & $\theta_{2}$ & $\theta_{3}$ & $\theta_{4}$ \\
\hline \multirow{2}{*}{ Australia } & 0.97 & $\mathbf{0 . 1 1 3 2}$ & 0.0152 & 0.0079 & 0.0028 \\
& $(0.94,1.00)$ & $\mathbf{( 6 . 6 8 )}$ & $(1.49)$ & $(1.51)$ & $(0.79)$ \\
\hline \multirow{2}{*}{ Botswana } & 0.91 & $\mathbf{0 . 8 1 5 8}$ & $\mathbf{0 . 0 6 9 0}$ & 0.0086 & -0.0144 \\
& $(0.88,0.94)$ & $\mathbf{( 1 5 . 7 0 )}$ & $\mathbf{( 2 . 2 3 )}$ & $(0.50)$ & $(-1.21)$ \\
\hline \multirow{2}{*}{ China } & 0.96 & $\mathbf{0 . 6 2 2 7}$ & $\mathbf{0 . 1 5 9 5}$ & $\mathbf{0 . 0 6 2 1}$ & -0.0043 \\
& $(0.93,1.00)$ & $\mathbf{( 5 . 4 0 )}$ & $\mathbf{( 2 . 3 0 )}$ & $\mathbf{( 1 . 7 1 )}$ & $(-0.17)$ \\
\hline \multirow{2}{*}{ Euro } & 0.98 & $\mathbf{1 4 . 2 5 8 7}$ & -2.2372 & -0.5179 & 0.1471 \\
& $(0.95,1.02)$ & $\mathbf{( 5 . 1 8 )}$ & $\mathbf{( - 1 . 3 4 )}$ & $(-0.61)$ & $(0.25)$ \\
\hline \multirow{2}{*}{ Japan } & 0.95 & $\mathbf{1 0 4 . 0 6 7 5}$ & 12.1563 & 2.0015 & 1.5849 \\
& $(0.92,0.98)$ & $\mathbf{( 5 . 5 3 )}$ & $(1.07)$ & $(0.33)$ & $(0.38)$ \\
\hline \multirow{2}{*}{ U.K. } & 0.99 & $\mathbf{1 6 . 5 6 1 3}$ & -2.7126 & -1.3395 & 0.7215 \\
& $(0.96,1.03)$ & $\mathbf{( 4 . 5 9 )}$ & $\mathbf{( - 1 . 2 4 )}$ & $(-1.21)$ & $(0.97)$ \\
\hline U.S.A. & 0.97 & $\mathbf{1 0 . 8 0 6 7}$ & $\mathbf{- 2 . 5 8 5 6}$ & -0.3570 & 0.4912 \\
& $(0.94,1.01)$ & $\mathbf{( 4 . 6 1 )}$ & $\mathbf{( - 1 . 8 3 )}$ & $(-0.49)$ & $(0.99 \mathrm{D})$ \\
\hline
\end{tabular}

In bold, significant coefficients at the 5\% level. 
Table 8: Descriptive statistics _ Volatility

\begin{tabular}{|c|c|c|c|}
\hline Country & Mean & Std. Deviation & Max. value \\
\hline Australia & 0.00578257 & 0.00522136 & 0.04652002 \\
\hline Botswana & 0.00345399 & 0.0034267 & 0.03339377 \\
\hline China & 0.00733205 & 0.00625214 & 0.05921048 \\
\hline Euro & 0.00674404 & 0.00600767 & 0.05963502 \\
\hline Japan & 0.00845568 & 0.0074312 & 0.05414589 \\
\hline U.K. & 0.0069458 & 0.00604987 & 0.07252345 \\
\hline U.S.A. & 0.00760255 & 0.00644484 & 0.0625233 \\
\hline Country & Mean & Std. Deviation & Max. value \\
\hline Australia & $6.06885 \mathrm{E}-05$ & 0.000130778 & 0.002164112 \\
\hline Botswana & $2.3667 \mathrm{E}-05$ & $6.8206 \mathrm{E}-05$ & 0.00111514 \\
\hline China & $9.28306 \mathrm{E}-05$ & 0.000182876 & 0.003505881 \\
\hline Euro & $8.15579 \mathrm{E}-05$ & 0.000176338 & 0.003556336 \\
\hline Japan & 0.0001267 & 0.0002461 & 0.00293178 \\
\hline U.K. & $8.48287 \mathrm{E}-05$ & 0.000192087 & 0.005259651 \\
\hline U.S.A. & $9.93162 \mathrm{E}-05$ & 0.000196583 & 0.003909163 \\
\hline
\end{tabular}


Table 9: Estimates of $\mathbf{d}$ under no autocorrelation

\begin{tabular}{|c|c|cc|}
\hline Series & \multicolumn{2}{|c|}{ Absolute returns } & \multicolumn{2}{|c|}{ Squared returns } \\
\hline Australia & $0.12(0.10,0.15)$ & $0.12 \quad(0.10,0.15)$ \\
\hline Botswana & $0.17(0.14,0.20)$ & $0.22 \quad(0.18,0.26)$ \\
\hline China & $0.13(0.10,0.15)$ & $0.11(0.09,0.14)$ \\
\hline Euro & $0.14(0.11,0.16)$ & $0.13(0.10,0.15)$ \\
\hline Japan & $0.17(0.15,0.19)$ & $0.15(0.13,0.18)$ \\
\hline U.K. & $0.12(0.10,0.14)$ & 0.09 & $(0.06,0.11)$ \\
\hline U.S.A. & $0.12(0.10,0.15)$ & 0.11 & $(0.09,0.14)$ \\
\hline
\end{tabular}

Table 10: Estimates of $\mathbf{d}$ under autocorrelation

\begin{tabular}{|c|l|l|l|}
\hline Series & \multicolumn{2}{|c|}{ Absolute returns } & \multicolumn{2}{c|}{ Squared returns } \\
\hline Australia & $0.17(0.12,0.22)$ & $0.15(0.11,0.20)$ \\
\hline Botswana & $0.16(0.13,0.19)$ & $0.05(0.02,0.08)$ \\
\hline China & $0.20(0.16,0.24)$ & $0.16(0.12,0.20)$ \\
\hline Euro & $0.19(0.16,0.24)$ & $0.15(0.11,0.19)$ \\
\hline Japan & $0.19(0.15,0.23)$ & $0.13(0.09,0.17)$ \\
\hline U.K. & $0.18(0.15,0.23)$ & $0.15(0.11,0.19)$ \\
\hline U.S.A. & $0.19(0.16,0.24)$ & $0.15(0.12,0.19)$ \\
\hline
\end{tabular}


Table 11: Estimates of $d$ based on a semiparametric method

\begin{tabular}{|c|c|c|c|c|c|c|c|}
\hline \multicolumn{8}{|c|}{ i) Absolute returns } \\
\hline Country / m & $\mathrm{T}^{0.30}$ & $\mathrm{~T}^{0.35}$ & $\mathrm{~T}^{0.40}$ & $\mathrm{~T}^{0.45}$ & $\mathrm{~T}^{0.50}$ & $\mathrm{~T}^{0.55}$ & $\mathrm{~T}^{0.60}$ \\
\hline Australia & 0.490 & 0.487 & 0.349 & 0327 & 0.297 & 0.238 & 0.248 \\
\hline Botswana & 0.500 & 0.345 & 0.401 & 0.362 & 0.340 & 0.367 & 0.310 \\
\hline China & 0.337 & 0.247 & 0.267 & 0.297 & 0.347 & 0.360 & 0.333 \\
\hline Euro & 0.409 & 0.267 & 0.400 & 0.322 & 0.302 & 0.274 & 0.266 \\
\hline Japan & 0.294 & 0.310 & 0.329 & 0.337 & 0.363 & 0.338 & 0.340 \\
\hline U.K. & 0.500 & 0.412 & 0.393 & 0.356 & 0.365 & 0.377 & 0.291 \\
\hline U.S.A. & 0.391 & 0.298 & 0.278 & 0.289 & 0.317 & 0.366 & 0.352 \\
\hline Lower 95\% & -0.274 & -0.212 & -0.175 & -0.145 & -0.119 & -0.099 & -0.081 \\
\hline Upper $95 \%$ & 0.274 & 0.212 & 0.175 & 0.145 & 0.119 & 0.099 & 0.081 \\
\hline \multicolumn{8}{|c|}{ ii) Squared returns } \\
\hline Country / m & $\mathrm{T}^{0.30}$ & $\mathrm{~T}^{0.35}$ & $\mathrm{~T}^{0.40}$ & $\mathrm{~T}^{0.45}$ & $\mathrm{~T}^{0.50}$ & $\mathrm{~T}^{0.55}$ & $\mathrm{~T}^{0.60}$ \\
\hline Australia & 0.433 & 0.356 & 0.347 & 0.319 & 0.260 & 0.207 & 0.190 \\
\hline Botswana & 0.354 & 0.178 & 0.284 & 0.243 & 0.205 & 0.195 & 0.179 \\
\hline China & 0.315 & 0.215 & 0.292 & 0.303 & 0.292 & 0.287 & 0.266 \\
\hline Euro & 0.497 & 0.261 & 0.376 & 0.275 & 0.268 & 0.208 & 0.202 \\
\hline Japan & 0.240 & 0.203 & 0.258 & 0.258 & 0.290 & 0.247 & 0.279 \\
\hline U.K. & 0.500 & 0.400 & 0.404 & 0.341 & 0.301 & 0.268 & 0.215 \\
\hline U.S.A. & 0.379 & 0.283 & 0.333 & 0.322 & 0.283 & 0.291 & 0.275 \\
\hline Lower $95 \%$ & -0.274 & -0.212 & -0.175 & -0.145 & -0.119 & -0.099 & -0.081 \\
\hline Upper 95\% & 0.274 & 0.212 & 0.175 & 0.145 & 0.119 & 0.099 & 0.081 \\
\hline
\end{tabular}

